\title{
MERUBAH STIGMA AKAN KEPATUHAN MASYARAKAT TERHADAP PROTOKOL KESEHATAN DI ERA PANDEMIC COVID-19 DI DESA SUNGAI TANDIPAH KECAMATAN SUNGAI TABUK BANJARMASIN
}

\author{
Mohammad Basit ${ }^{1 *}$,Dandy Febri Deswindra ${ }^{2}$, Diar $^{3}$, Fatmawati $^{4 *}$, Laili Fahriza ${ }^{5}$, \\ Rico Naim ${ }^{6}$, Saldilawaty ${ }^{7}$,Uswatun Hasanah ${ }^{8}$ \\ 1,2.3,4,5,6,7,8 Fakultas Kesehatan, Progam Studi sarjana Keperawatan dan Profesi Ners, \\ Universitas Sari Mulia Banjarmasin \\ *email:syafabasit@gmail.com \&fatmawati74717@gmail.com
}

\begin{abstract}
ABSTRAK
Covid-19 yaitu penyakit menular menyerang saluran pernafasan yang disebabkan oleh coronavirus. Wabahnya dimulai di Wuhan, Tiongkok, pada Desember 2019. Covid-19 terkonfirmasi masuk ke Indonesia pada awal Maret dan hingga kini 3,8 juta jiwa penduduk Indonesia positif terserang virus Covid-19. Penerapan protokol kesehatan 5M yaitu menggunakan masker, mencuci tangan dengan sabun dan air mengalir, menjaga jarak, menjauhi kerumunan, dan mengurangi mobilasasi juga sampai saat ini terus digalakkan karena obat resmi untuk melawan Covid-19 belum ditemukan, upaya tersebut guna memutus mata rantai penyebaran Covid-19. Penerapan protokol kesehatan ini tidak akan maksimal apabila tidak disertai dengan partisipasi masyarakat dalam mematuhi protokol kesehatan, sehingga diperlukan perilaku patuh. Akan tetapi, stigma negatif terhadap penggunaan masker di masyarakat dan cukup jauhnya jarak ke pelayanan kesehatan menjadi masalah utama. Metode pemecahan masalah yang sesuai adalah dengan pendekatan community development. Program pengabdian dilakukan melalui 3 tahapan yaitu tahap persiapan, tahap pelaksanaan dan tahap evaluasi. Sasaran yaitu masyarakat RT 01, 02, 03, dan 04 di desa Sungai Tandipah kecamatan Sungai Tabuk Banjarmasin. Secara khusus hasil kegiatan pengabdian ini yaitu 1.461 laki-laki (52\%) dan 1361 perempuan (48\%) yang terdiri dari 4 RT yakni RT 01,02,03 dan 04 warga di wilayah desa Sungai Tandipah kecamatan Sungai Tabuk. Desa Sungai Tandipah terdapat 5 orang kader yang aktif. Sebelumnya hampir semua kelompok sasaran pengabdian kurang mematuhi protokol kesehatan terutama dalam hal memakai masker. Setelah di berikan pengetahuan tentang pentingnya mematuhi protokol kesehatan di era pandemi covid-19, kelompok sasaran pengabdian sudah mulai meningkatkan kepatuhan protokol kesehatan terutama menggunakan masker.
\end{abstract}

Kata Kunci: Covid-19, Kepatuhan, stigma, Community Development, Banjarmasin

\section{A. PENDAHULUAN}

Pada awal tahun 2020, virus

dinamakan dengan Novel

yang belum pernah terdeteksi

Coronavirus

(SARS-CoV-2),

sebelumnya berhasil menyebar luas

sedangkan penyakitnya dikenal

keseluruh dunia. Virus tersebut

dengan Coronavirus disease 2019 
(Covid-19). Covid-19 yaitu penyakit menular menyerang saluran pernafasan yang disebabkan oleh coronavirus(WHO,2020). Hingga saat ini 4,37 juta jiwa di seluruh dunia meninggal akibat Covid-19 (WHO, 2021).

\section{Covid-19 terkonfirmasi} masuk ke Indonesia pada awal Maret dan hingga kini 3,8 juta jiwa penduduk Indonesia positif terserang virus covid-19. DKI Jakarta sebagai ibu kota Indonesia sendiri menduduki peringkat satu dengan kasus terbanyak positif Covid-19 (COVID-19, 2021). Banyaknya kejadian Covid-19 membuat beberapa wilayah di Indonesia saat ini sedang melaksanakan Pemberlakuan Pembatasan Kegiatan Masyarakat (PPKM), sesuai dengan Mendagri Nomor 28 Tahun 2021 tentang Pemberlakuan Pembatasan Kegiatan Masyarakat (PPKM) Level 4 Covid-19 di Wilayah Sumatera, Kalimantan, Sulawesi, Nusa Tenggara, Maluku, dan Papua. Kalimantan Selatan sendiri masuk salah satunya yaitu di kota Banjarmasin (CNN, 2021).
Penerapan

protokol kesehatan $5 \mathrm{M}$ juga sampai saat ini terus digalakkan mulai dari menggunakan masker, mencuci tangan dengan sabun dan air mengalir, menjaga jarak, menjauhi kerumunan, dan mengurangi mobilasasi (Kemenkes RI, 2021) karena obat resmi untuk melawan Covid-19 belum ditemukan, upaya tersebut guna memutus mata rantai penyebaran Covid-19 (Apriyati, 2021). Penerapan protokol kesehatan ini tidak akan maksimal apabila tidak disertai dengan partisipasi masyarakat dalam mematuhi protokol kesehatan, sehingga diperlukan perilaku patuh (Afrianti, 2021). Kepatuhan adalah suatu bentuk ketaaatan (Rosa, 2018) perilaku patuh dipengaruhi oleh banyak faktor salah satunya adalah stigma. Stigma negatif dari lingkungan yang didapat pada masyarakat yang mengakibatkan masyarakat memiliki kendala dalam mematuhi Protokol Kesehatan, mengakses dan mandapatkan informasi kesehatan sehingga perilaku dalam menerapkan protokol kesehatan menjadi tidak teratur (Muhardiani, 2017). 
Gambar 1. Pengkajian kepada salah satu anggota masyarakat yang tidak mengenakan masker saat bersosialisasi.

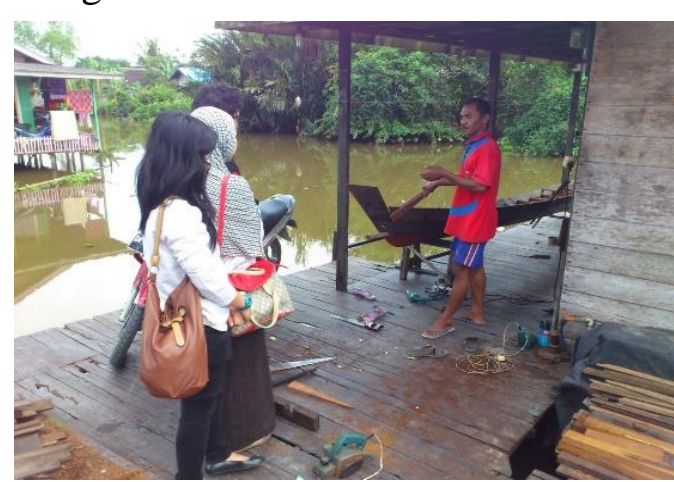

Desa Sungai Tandipah Kecamatan Sungai Tabuk bertepatan di kota Banjarmasin, Kalimantan Selatan menjadi sorotan karena penerapan Protokol Kesehatan yang nampak kurang, terlihat pada gambar di atas.

$\begin{array}{ccc} & \text { Berdasarkan latar belakang } \\ \text { diatas maka ketidakpatuhan }\end{array}$ penerapan protokol kesehatan menjadi salah satu faktor penyebab meningkatnya Covid-19 sehingga sangat ada hubungan stigma di lingkungan masyarakat dengan kepatuhan dalam penerapan Protokol Kesehatan.

\section{B. METODE PELAKSANAAN}

Metode pemecahan masalah yang sesuai adalah dengan pendekatan community development. Pengabdi bekerjasama dengan anggota masyarakat untuk melaksanakan program pengabdian. Program pengabdian yang dilakukan melalui 3 tahapan yaitu :

1) Tahap Persiapan : Kerjasama antara tim pengabdi dan kelompok masyarakat untuk mengkaji dan menentukan kebutuhan yang diperlukan oleh masyarakat.

2) Taha Kedua : Mempersiapkan segala sarana dan prasarana yang dibutuhkan, sekaligus merencanakan pelaksanaan kegiatan dan waktu pelaksanaannya. Kegiatan di laksanakakan secara online menggunakan zoom meeting di sebar melalui media social kelompok RT 01, 02, 03 dan 04 desa Sungai Tandinpah.

3) Tahap Ketiga melakukan evaluasi dengan memberikan pertanyaan terkait materi penyuluhan atau edukasi yang telah di sampaikan kepada masyarakat

\section{HASIL DAN PEMBAHASAN}

Berdasarkan data masyarakat RT 01, 02, 03 dan 04 desa Sungai Tandinpah yaitu 1.461 laki-laki (52\%) dan 1361 perempuan $(48 \%)$ 
yang terdiri dari 4 RT yakni RT 01,02,03 dan 04 warga di wilayah desa Sungai Tandipah kecamatan Sungai Tabuk. Desa Sungai Tandipah menurut data yang ada terdapat 5 orang kader yang aktif. Berdasarkan data banyak warga yang tidak ingin memeriksakan kesehatannya kepelayanan kesehatan dikarenakan masa pandemi dan cukup jauh jarak ke pelayanan kesehatan. Data menunjukkan penyakit tertinggi yang dialami adalah ISPA. Hampir semua warga yang ada disana kurang mematuhi protokol kesehatan terutama dalam hal memakai masker. Kemauan yang tinggi untuk mematuhi protocol kesehatan dan keberanian diri untuk memeriksakan kesehatan kelayanan kesehatan terdekat di karenakan sikap masyarakat itu sendiri, sikap merupakan konsep terpenting dalam psikologis sosial sehingga masyarakat mempunyai anggapan positif dan kebermanfaatan yang sangat baik apabila mau melakukannya. Wawan, (2010).

Kecamatan sungai tabuk masuk kedalam zona merah pada bulan mei, dan saat ini masih kedalam kategori resiko tinggi
Covid-19, akan tetapi data positif Covid yang masih banyak belum terdeteksi dikarenakan sebagian besar penduduk tidak melakukan swab/test antigen sehingga sangat sedikit yang dinyatakan positif. Melaui sikap, akan terjadi proses kesadaran yang memerlukan Tindakan nyata baik dari individu atau kelompok kehidupan sosial untuk mematuhi protokol kesehatan dan mau memeriksakan diri ke layanan kesehatan apa bila ada mengalami keluhan tentang covid19. Wawan (2010).

Secara umum $85 \%$ warga di desa Sungai Tandipah kecamatan Sungai Tabuk pada kegiatan pengabdian ini dinilai cukup memuaskan. Hal ini dikarenakan mayoritas warga di desa Sungai Tandipah mengungkapkan bahwa masih banyak masyarakat yang belum memahami terkait pandemi Covid-19. Karena ketidaktahuan masyarakat dan rasa ingin tahu yang tinggi serta sikap postif masyarakat cenderung tindakannya menyenangi kegiatan, serta mendekati kegiatan. wawan, (2010)

Sebagian besar penduduk tidak mematuhi protokol kesehatan 
seperti memakai masker. Mayoritas warga mengatakan enggan menggunakan masker dikarenakan cuma berada di desa dan mereka beranggapan bahwa virus corona itu hanya berada dikota.

$$
\text { Pembentukan kepatuhan }
$$
prilaku pada pengabdian ini sangat penting sekali sehingga masyarakat mematuhi protocol kesehatan, Tindakan kepatuhan prilaku seperti terbentuknya prosedur tindakan contoh terlihat masyarakat senang mengikuti kegiatan terbukti dengan ucapan terimakasih sudah melaksanakan kegiatan pengabdian, selanjutnya masyarakat memahami dengan baik materi yang di sampaikan, selanjutnya masyarakat ingin mematuhi protocol Kesehatan serta pencegahannya, wawan, (2010).

Di tengah situasi pandemi Covid-19 muncul stigma yang memperparah keadaan negeri, stigma di masyarakat membuat upaya pemutusan penularan covid-19 menjadi terkendala. Stigma merupakan penghalang terbesar dalam mencegah terjadinya penularan Covid-19. Stigma dalam hal ini adalah sikap dan perilaku negatif seseorang terhadap protokol kesehatan yang ditetapkan pemerintah. Sehingga dalam pengabdian ini mengidentifikasi bentuk stigma masyarakat terhadap protokol Kesehatan seperti menggunakan masker maka positif terkena covid-19, rajin cuci tangan sok bersih.

Stigma muncul diawali karena ketidaktahuan masyarakat tentang protokol kesehatan, khususnya dalam mekanisme penularan Covid-19. seiring berjalannya waktu sudah 1 tahun Covid-19 menyerang negeri, diawal pandemi masyarakat benar benar takut terpapar Covid-19 dibandingkan saat ini. saat ini masyarakat lebih berani menghadapi pandemi karena tuntutan ekonomi, dan bahkan tidak memperdulikan protokol kesehatan yang ada.

Hal ini dikarenakan pengetahuan terkait protokol kesehatan harus terus diberikan, terutama dalam melakukan aktivitas apapun tetap harus mengikuti protokol kesehatan yang telah ditetapkan pemerintah.

Pemberian pengetahuan tentang protokol kesehatan kepada 
tokoh masyarakat sangat penting dilakukan petugas kesehatan, agar tokoh masyarakat dapat membantu, memberikan contoh untuk memutus penularan Covid-19 dan menyebarkan kembali pengetahuan yang telah didapat dari tenaga kesehatan kepada masyarakat lainnya. Mematuhi penggunaan Protokol Kesehatan di era pandemic covid-19 di lingkungan masyarakat merupan kunci sukses untuk menekan penyebaran virus covid-19 dengan selalu melakukan $5 \mathrm{M}$ penerapan memakai masker, menjaga jarak, mencuci tangan dengan sabun atau handsanitizer, menghindari kerumunan dan

\section{DAFTARPUSTAKA}

Afrianti Novi, Cut Rahmiati. (2021). Faktor Yang Mempengaruhi Kepatuhan Masyarakat Terhadap Protokol Kesehatan Covid. Jurnal Ilmiah Permas : Jurnal Ilmiah STIKES Kendal, Vol. 11, No.1.https://doi.org/10.32583/psk $\underline{\text { m.v11i1.1045 }}$

Aulia, Gina, dkk. (2021). Edukasi Pencegahan Covid-19 Dengan Protokol Kesehatan 5M Dan mengurangi mobilitas (Kemenkes RI, 2021).

\section{KESIMPULAN}

1) Masyarakat yang kurang pengetahuan tentang pandemi Covid-19 memiliki resiko tinggi untuk terjangkit penyakit tersebut.

2) Sikap sosial yang positif akan membentuk perilaku kepatuhan patuh terhadap protocol Kesehatan selama pandemic covid-19.

3) Stigma yang postif akan terbentuk dengan adanaya peningkatan pengetahuan

4) Kapatuhan masyarakat akan meningkat dengan adanya edukasi secara berkelanjutan.

Pentingnya Multivitamin di Masa Pandemi Covid-19. JAM : Jurnal Abdi Masyarakat, Vol.2, No.1. http://openjournal.wdh.ac.id/ind ex.php/JAM/article/view/138/12 $\underline{1}$

CNN Indonesia. (2021). Daftar Daerah PPKM Level 4 di Seluruh Indonesia. https://www.google.co.id/amp/s/ www.cnnindonesia.com/nasional 
/20210810065128-20-

678512/daftar-daerah-ppkm-

level-4-di-seluruh-

indonesia/amp.

Kalselprov.go.id. (2021). Peta Sebaran

COVID-19 di Kalimantan

Selatan.https://corona.kalselprov

.go.id/

Kemenkes RI. (2021). 5 M Dimasa

Pandemi COVID-19 di

Indonesia. $\quad$ URL:

http://www.padk.kemkes.go.id/a

rticle/read/2021/02/01/46/5-m-

dimasa-pandemi-covid-19-di-

indonesia.html. Diakses tanggal

8 April 2021.

Muhardiani, dkk. (2015). Hubungan

Antara Dukungan Keluarga,

Motivasi Dan Stigma

Lingkungan Dengan Proses

Kepatuhan Berobat Terhadap

Penderita Tb Paru Di Wilayah

Kerja Puskesmas Gang Sehat.

Pontianak. JUMANTIK : Jurnal
Mahasiswa dan Peneliti

Kesehatan, Vol.2, No.3.

http://openjurnal.unmuhpnk.ac.i

d/index.php/JJUM/article/view/1

$\underline{37}$

Ananingsih, Pangisti.D., Rosa, Elsye.M. (2016). Kepatuhan 5 Momen Hand Hygiene pada Petugas Laboratorium Klinik Cito Yogyakarta (Action Research). JMMR: J Medicoeticolegal Dan Manaj Rumah Sakit, Vol.5, No.1.https://doi.org/10.18196/jm $\underline{\mathrm{mr} . v 5 i 1.820}$

World Health Organization. 2020. Corona virus disease 2019(COVID-19)

World Health Organization. 2021. Corona virus disease 2019(COVID-19)

Wawan, S \& Dewi M. (2010). Teori \& pengukuran Pengetahuan, sikap, dan prilaku manusia. Yogyakarta: Nuha Medika. 